\title{
大麻成分の中枢効果：有用性と危険性
}

\author{
三島 健一, ${ }^{*}$ 入江 圭一
}

\section{Central Effect of Components of Cannabis: Utility and Risk}

\author{
Kenichi Mishima* and Keiichi Irie \\ Faculty of Pharmaceutical Science, Fukuoka University; 8-19-1 Nanakuma, Jonan-ku, Fukuoka 814-0180, Japan.
}

(Received August 2, 2019)

\begin{abstract}
Cannabis contains over 700 known cannabinoids, terpenoids, flavonoids, and so on; however, the roles and importance of these components have yet to be fully understood. $\Delta^{9}$-Tetrahydrocannabinol (THC) is believed the most psychoactive component in cannabis, whereas cannabidiol (CBD), cannabinol, and cannabigerol are the most well-known non-psychoactive components. THC, but not CBD, has been shown to produce abnormal behavior in animals; these effects are caused, at least in part, by binding to cannabinoid receptor type $1\left(\mathrm{CB}_{1}\right)$ in the brain. Regarding the risks associated with cannabis use, acute effects of THC, such as a "high", cognitive deficits, and irritability, are considered more important than potential dependence. On the other hand, CBD has shown anticonvulsant, anti-inflammatory, immunosuppressive, analgesic, and anticancer effects. However, CBD has very low affinity (in the micromolar range) for the $\mathrm{CB}_{1}$ receptor, as well as for the $\mathrm{CB}_{2}$ receptor, and its underlying mechanism remains obscure. In this review, we demonstrate that THC induces abnormal behavior such as catalepsy-like immobilization, spatial memory impairment, and high and low sensitivity to ultrasonic vocalization after an aversive air-puff stimulus. Moreover, we demonstrate that THC and CBD improve brain injury in middle cerebral artery occlusion in a mouse model through different mechanisms. These findings suggest the need to discuss the recent development of "THC and CBD pharmacology" in animal studies, as well as the utility and risk of various cannabis components in humans.
\end{abstract}

Key words_— cannabis; $\Delta^{9}$-tetrahydrocannabinol; cannabidiol; pharmacology; animal study

\section{1.はじめに}

大麻（cannabis, marijuana）は，世界で最も乱用 されている薬物で, WHO/Expert Committee on Drugs Dependence (ECDD) の統計によれば，2016 年度において約 1 億 9 千万人が世界で使用している と推定されている. わが国においても，平成 25 年 以降, 大麻事犯による検挙者数が増加し, 平成 29 年度では 3000 人を超え, 昨年度は過去最多になつ た. その検挙者数の中で 20 歳代以下の若年層の占 める割合が $50 \%$ を超え，低年齢層への広がりが社 会的問題となっている.11)若者の間に広がる大麻污 染は，「好奇心・興味本位」や「その場の雾囲気な ごによるファッション感覚」などを特徵とし，イン ターネットの密売サイトを介した大麻自家栽培の急 増，若者の海外経験や外国人密売者からの大麻入手

福岡大学薬学部 (T814-0180 福岡市城南区七隈 8-19-1) *e-mail: kenichi@fukuoka-u.ac.jp

本総説は, 日本薬学会第 139 年会シンポジウムS58 で 発表した内容を中心に記述したものである.
の容易さが原因に挙げられる，さらに，大麻は中毒 性が低いと報告され, 海外では医療大麻としてある いは啫好品として合法化されたことが，この傾向に 拍車をかけている. そのため, 大麻使用に対して安 全だという間違つた認識が広がつている。このよう な大麻に関して誤つた知識が拡大する要因として, 大麻の薬理作用が多様であり，いまだに全容が解明 されていないことにある.

近年, 大麻草に含まれる主成分のテトラヒドロカ ンナビノール（ $\Delta^{9}$-tetrahydrocannabinol; THC）の

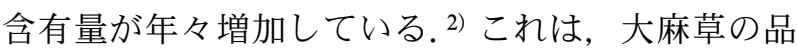
種改良や栽培技術の向上によるものである，例えば， THC が含まれる花穂の部分が大きな sinsemilla（種 なしの意味）などの新たな品種が市場に出回ってい る.さらに，超臨界法など高度な抽出技術を用いた 高純度の THC を始めとする大麻成分が精製されて いる.これらは，サプリメントとして，あるいは食 品の中に入れられ, クッキー, グミ, ガム, キャン ディー，チョコレート，アイス，アルコールなど新 
たな大麻食品が登場している。ささらにこれまでの 乾燥大麻による喫煙に加えて，THC が高濃度の才 イル状のものを電子パイプで喫煙するものも出てき

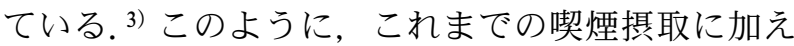
て，経口で簡単に摂取でき，手に取り易い大麻製品 が増え，高濃度 THC 含有の製品が流通しているこ とが，大麻のヒトへの作用を複雑化している.

本稿では，大麻の薬理作用を明確にするため，大 麻の有用性と危険性について，「日本薬学会第 139 年会一般シンポジウム S58, 薬物乱用のトレンド : ポスト危険ドラッグとしての大麻問題を考える」で われわれが報告した研究に関する知見を紹介する.

\section{2. 大麻について}

大麻（Cannabis sativa L.，アサ科）は，世界で 最も古い繊維作物のアサであり, 温帯地方から熱帯 地方まで広範囲にわたつて生育する雌雄異株の一年 生草で，高さは 2-3 m, 乱用には葉や樹脂が用いら れる，特に，雌株には幻覚作用を有する樹脂を多量 に分泌し，開花期の初期が最も多くなる．大麻，別 名「麻 (アサ)」は，わが国では弥生時代から既に 衣類として重要な位置を占めていたといわれ，奈良 朝時代の「万葉集」などにも掲載されているが，こ れを快楽や宗教的秘事の目的で使われた記録はな い。このことは，幻覚や快楽を起こすような物質の THC が当時の日本の麻には含まれていなかったと 推測できる。事実，現在，わが国で栽培されている 大麻は，THC を含まない「無毒大麻」である。そ の後の中央アジアを原産地とした THC を多く含 み，幻覚や麻酔作用の強いインド大麻（Cannabis sativa L. var. indica LAMARCK）が世界各地に分布 し，日本産地の大麻も污染された結果と言われてい る。 THC を多く含んだインド大麻は, 繊維のほ か，痛みを和らげ，陶酔感や多幸感をおこす作用が あることが， 3000 年前から知られていたため，宗 教, 戦争，占術，医術あるいは快楽の目的で用いら れるようになった。わが国では，快楽を目的とした 大麻が広く乱用されるようになったのは 1960 年以 降である.

医学的には，大麻の持つ陶酔感や麻酔作用を基礎 に古代イラン医学が発達し，中国，インド医学に広 がった。わが国では，明治 19 年（1886 年）の日本 薬局方第 1 局から昭和 7 年（1932 年）の第 5 局ま で印度大麻の名で収載され，鎮痛薬，麻酔薬として
取り扱われてきたが，優れた医薬品が開発されるこ とで局方に収載されなくなった，そのため，よく麻 薬性鎮痛薬と混同されがちであるが，薬理学的には 麻薬とは異なり, 幻覚薬としての精神異常誘発物質 に属する。

\section{3. 大麻がヒトに及ぼす影響}

大麻を喫煙すると， 2, 3 分以内に使用者の心拍数 は 1.5-2 倍に増え，血圧は上昇し，目の血管が膨張 して目が赤くなる。 その後, 10 分以内に多幸感, あるいは「ハイ」を感じ，1-3 時間程度持続する. 中には，口の渴きを覚えたり，ひどく空腹になった りすることもある．手が震えて冷たくなることもあ る．陶酔感がしばらく続いた後，眠くなることがあ る。一方，食物や飲料などに混ぜられた大麻を経口 摂取すると, 通常 30 分から 1 時間程度してから作 用が緩やかに始まり，4 時間程度とより長時間持続 する. ${ }^{4,5)}$ このように大麻の喫煙は，経口摂取に比べ て THC の吸収が数倍よく，発現も早いことから喫 煙が好まれている．また，経口摂取の場合，作用が 現れる 30 分以内に間違って多量に大麻を含んだ食 物や飲料を摂取すると過量投与による急性中毒にな る場合がある。大麻によって引き起こされる急性中 毒の症状は極めて深刻で，患者は入院の必要があ り，初期診断では統合失調症と混同され易く，特に 何かの力に支配されているような“させられ妄想”, “誇大妄想”など妄想型統合失調症にかなり似通つ ている。一般的な大麻夕バコには 0.5 $-1 \mathrm{~g}$ の大麻草 を含み, THC 含有量は 5-150 mg の開きがあるた め，喫煙したときに吸収される THC の実際の服用 量は容易に定量できない.

大麻による精神活動の変化としては知覚機能, 思 考過程，情動あるいは気分などに異常が現れる，そ の作用の特徵は, 個人の性格，気分あるいは効果の 期待度, 'set’と 'setting' と呼ばれている喫煙時の 環境条件によって，また，代謝酵素など使用者側の 要因と, 用量や摂取方法などの大麻側の要因によっ て大いに左右される，例えば，不安をもって吸煙す ると不機嫌になり，猜疑的になる，これが高じると 緊張や恐怖におそわれ，パニックを引き起こすこと もある。一方では，躁病に似た気分の高揚，誇大的 になって饒舌になり，突発的に哄笑したりし，行動 は活発になるが，逆に多幸感が強く，緊張は解け， 非活動的，周囲への無関心など統合失調症様症状な 

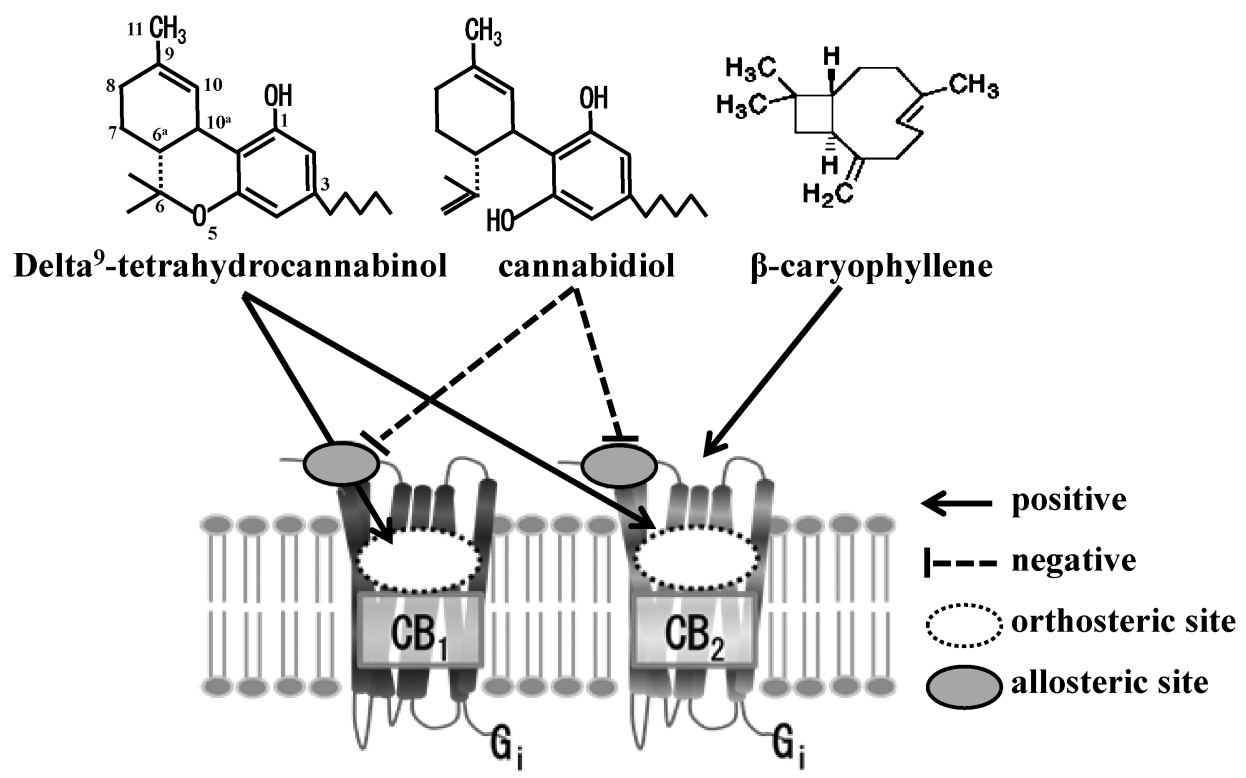

Fig. 1. Cannabinoid Structure and Receptors

$\Delta^{9}$-Tetrahydrocannabinol is the most psychoactive component of cannabis, a parital CB receptor agonist, while cannabidiol, an inverse $\mathrm{CB}$ receptor agonist, is the most well-known non-psychoactive component. Beta-caryophyllene, which is known as a $\mathrm{CB}_{2}$ receptor agonist, is a common and often abundant terpene found in cannabis.

ど相反する行動変容がみられることがある.このよ うな特徵は他の乱用薬物の作用様式と全く異なる.

大麻による精神作用としては，酩酊時には，ま ず，知覚が鋭敏になり，色彩が異常に鮮やかに見 え，見るものの形は歪み，影まで色がつき，視覚機 能の異常が現れる. また, 音も強く感じられ, 聴覚 機能や体感の感覚異常がおきる。時間・空間の認知 も障害され，時間の経過は極めてゆっくりと感じら れたり，近くのものが遠くに見えたりする．思考過 程も障害され，注意集中はできなくなり，連想は乱 れ，考え方は非現実的になり，つぎつぎに妄想がお しょせる。被暗示性が著しく増大し，自発性の低 下, 感情の平板化, 記憶障害や判断力障害を起こ す. ${ }^{6)}$

大麻常用者は，社会適応性が低下して，总け者と なり無気力となる無動機症候群が現れることがあ る。また，慢性人格障害を伴う大麻精神病をもたら すこともある。これは体内に蓄積された THC とそ の活性代謝産物が関与するといわれる。したがつ て，精神病性疾患の病歴のある患者は大麻を服用す ると精神病を発症する可能性が高くなる，大麻精神 病の症状の中で幻覚妄想や錯乱状態は乱用をやめた 後でも“フラッシュバック”として再燃する。この 現象は覚せい剤や幻覚薬の LSD25 にもみられる.

\section{4. 大麻成分}

大麻草中には酸素と水素と 21 個の炭素からなる カンナビノイド (cannabinoid) 類と呼ばれる成分 が約 140 種類も含まれている。これら以外にアルカ ロイド類，フラボノイド類，テルペン類など約 700 種類以上の成分が含まれていることが報告されてい る. ${ }^{7)}$ その中でも THC 及びカンナビジオール (cannabidiol; CBD） は，大麻による薬理作用の中心活 性物質だと考えられている（Fig. 1)。THC は，油 状物質で，非常に脂溶性が高い化合物であるため, 脂肪に分布，蓄積する性質があり，水には不溶で, エーテルなどの有機溶媒によく溶ける。 また, THC は植物中では不活性のテトラヒドロカンナビ ノール酸（tetrahydro cannabinolic acid; THCA）と して含まれているが，大麻草をタバコとして吸煙す るとき，その熱によって容易に 2 位のカルボキシ基 が脱炭酸されて THC となり，強力な薬理作用を現 すようになる，さらに，体内で多くの代謝活性物が 生じることが知られている。例えば，THC は，体 内で 11 位に水酸基が結合された $11-\mathrm{OH}-\Delta^{9}-\mathrm{THC} に$ 変換され，これ自体に強い精神作用があると言われ ている. ${ }^{8)}$ また, 大麻や THC は使用条件によって 作用が変化することが知られている.9 さらに, THC による薬理作用の一部を CBD が調節してい ることが報告されている. ${ }^{10)}$ このように大麻には多 
種類の成分を含有し，これらが複雑に絡まり，環境 条件及び使用条件によって多彩な薬理作用を導き出 している.

THC は，大麻による精神作用の本体とされ，動 物実験では, 不安・嫌悪感の惹起, ${ }^{11)}$ 社会性の減 少, ${ }^{12)}$ 攻撃性の増大, ${ }^{13)}$ 情報処理障害の発現, ${ }^{14)}$ 空 間記憶障害, ${ }^{15)}$ うつ様症状の発現16) が確認されてい る. THC は，精神作用以外にも，鎮痛作用，食欲 増進作用や鎮痓作用など大麻と同じ薬理作用を示 す。一方，CBD は THC とは異なり，精神作用を 引き起こさないとされ，動物実験において，鎮痛作 用，抗不安作用，抗炎症作用，免疫抑制作用などが 報告されている，加えて，カンナビノイド類以外で も，テルペン類の $\beta$-caryophyllene $(\beta$-CPH) が鎮 痛作用，抗炎症作用を持つ物質として注目されてい る（Fig. 1)。しかし，大麻による薬理作用の中で， 上述したヒトの多幸感，感覚異常，幻覚作用などは 動物実験では観察されておらず，作用機序などが明 らかになっていないものが多い。これらの原因は， 大麻がカンナビノイド類を中心とした多種多様な成 分を含有しており，それぞれの成分で薬理作用が異 なっている．このように大麻の薬理作用は，薬理活 性成分の多様性及び THC 含有量の変化により複雑 化しており，正しい薬理作用を知るためにも，薬理 活性成分 1 つ 1 つの薬理作用を明確にしていくこと が重要である.

\section{5. 内因性カンナビノイドシステム}

大麻草による薬理作用は, 主にカンナビノイド (cannabinoid; CB) 受容体によって引き起こされる. $\mathrm{CB}$ 受容体は， 2 つのサブタイプ $\mathrm{CB}_{1}$ 受容体と $\mathrm{CB}_{2}$ 受容体があり, 膜 7 回貫通で Go あるいは Gi タン パク質と共役した受容体である. $\mathrm{CB}_{1}$ 受容体は，黒 質，淡蒼球，海馬，小脳の分子層，大脳皮質などを 中心に強く発現し，その発現量は GABA 受容体や グルタミン酸受容体に匹敵するほど存在することか ら，運動，学習・記憶といつた脳の高次機能調節に おいて重要な役割を果たしていることが考えられて いる。，一方， $\mathrm{CB}_{2}$ 受容体は，脾藏及び扁桃腺に多く 発現しており，細胞ではB 細胞，natural killer 細 胞，マクロファージなどに発現している，そのため, $\mathrm{CB}_{2}$ 受容体は免疫反応や炎症反応の調節を行ってい るとされているが， $\mathrm{CB}_{1}$ 受容体に比べるとまだ詳細 はわかっていない. $\mathrm{CB}_{1}$ 受容体の活性化によって,
アデニル酸シクラーゼの阻害による cAMP の減 少，電位依存性 $\mathrm{K}^{+}$チャネルの活性化，電位依存性 $\mathrm{P} / \mathrm{Q}$ 及び $\mathrm{N}$ 型の $\mathrm{Ca}^{2+}$ チャネルを阻害し，アセチ ルコリン，ドパミン，セロトニン，グルタミン酸，

GABA など様々な神経伝達物質の調節が行われて いることが知られている. ${ }^{17)} \mathrm{THC}$ は，CB 受容体の 部分作動薬であり，一方， $\mathrm{CBD}$ は， $\mathrm{CB}_{1}$ 受容体を アロステリックモデュレーターとして調節している

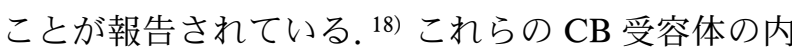
因性のリガンドとして, $N$-arachidonoylethanolamide (anandamide; AEA), 2-arachidonoyl glycerol (2-AG), 2-arachidonoyl glycerol ether, oleamide など脂質分 子が発見されている. Anandamide は，1992 年に Devane らによってブタの脳から，2-AG は，1995 年に Sugiura らがラットの脳より，同時期に Mechcoulum らがイヌの小腸より同定した. ${ }^{19-21)}$ 近 年の研究から，これらの脂質分子の内因性リガンド が，逆行性に神経終末における $\mathrm{CB}_{1}$ 受容体を介し て神経伝達物質の放出を制御していることが明らか となり， $\mathrm{CB}_{1}$ 受容体と内因性リガンドが高次機能に 関与していると示唆されている. ${ }^{22)}$ 一方，2003 年に は，Rioli らが，ラットの脳より $\alpha$-へモグロビンの 9 残基のアミノ酸からなるへモプレシンを同定し た. ${ }^{23)}$ モプレシンは，ナノモルという低濃度で効 果を示し, $\mathrm{CB}_{1}$ 受容体の内在性のインバースアゴニ ストであり，血圧低下作用，食欲抑制作用，鎮痛作 用を示すことが明らかになりつつある. ${ }^{24)}$ さらに, 大麻喫煙によって血中の一酸化炭素へモグロビンが 増加し，酸素の運搬に支障を来たすことから，へモ プレシンの薬理作用がヒトにどのように影響を及ぼ しているか興味深い。しかし，大麻草を含めたカン ナビノイドを摂取したときの内因性リガンドの動態 について不明なことも多く, 生体内の役割について も未解明な部分が多い。また，THC と CBD など 大麻草に含まれる成分の作用機序が複雑であるた め, 大麻の薬理作用を理解することを難しくしてい る.

\section{6. 動物実験から見た大麻の有用性}

6-1. THC による鎮痛作用 大麻成分による 正常ラットの痛覚反応に対する影響を調べるために, フィラメントを用いた von Frey test とアセトンを 用いた冷覚反応を利用した（Fig. 2)。THC 0.5, 1 $\mathrm{mg} / \mathrm{kg}$ を腹腔内投与することで, フィラメントに 

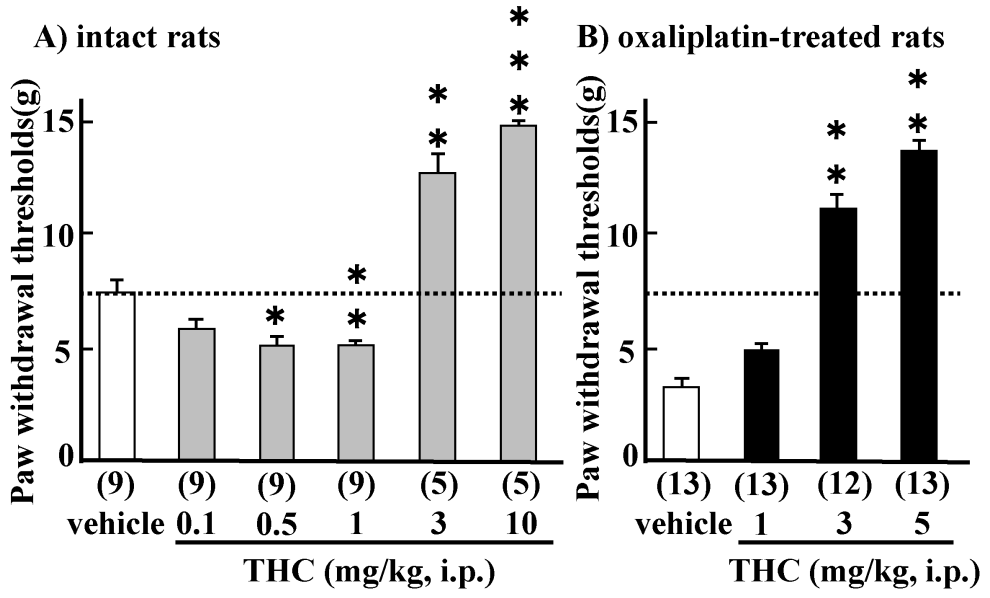

Fig. 2. Antinociceptive Effects of THC on Oxaliplatin-induced Mechanical Allodynia in Rats

(A) THC was administered to intact rats, i.p. 60 min before the von Frey test. (B) Oxaliplatin $(4 \mathrm{mg} / \mathrm{kg}$ ) was administered i.p. on 2 consecutive days per week for 4 weeks (on days 1, 2, 8, 9, 15, 16, 22, and 23). Mechanical allodynia could be observed in the hind paw starting from day 10 to 28 by the von Frey test. THC was administered to oxaliplatin-treated rats, i.p. $60 \mathrm{~min}$ before the test on day 28 . All values are expressed as mean \pm S.E.M. ${ }^{*} p<0.05,{ }^{* *} p<0.01,{ }^{* * *} p<0.001 v s$. vehicle group (one-way ANOVA followed by Dunnett's test).

よる機械的刺激に対する反応閾值は vehicle と比較 して有意に低下した。一方, THC $3,10 \mathrm{mg} / \mathrm{kg}$ を 腹腔内投与することで, フィラメントに対する反応 閾值は vehicle と比較して有意に痛覚の反応閾值が 上昇した。しかし，THCは冷覚反応を変化させな かった。 また，CBD はいずれも変化しなかった。 次に，白金系抗がん剂オキサリプラチン (L-OHP) により生じる末梢神経障害に対する大麻成分の影響 を調べた.このモデルは, 正常ラットに比べ, フィ ラメントによる機械的刺激に対する反応閾值を低下 させ，機械的アロディニアを引き起こした，THC $3,5 \mathrm{mg} / \mathrm{kg}$ の腹腔内投与は, このモデルに対して 用量依存的に改善した。しかし，CBD は改善しな かった.このことから, 大麻草による鎮痛作用は, CBD ではなく, THC の可能性が高い。また, THC は，正常ラットでは，フィラメントによる機 械的刺激に対して二相性の反応を示し，抗がん剂に よる末梢神経障害に対しては用量依存的な改善作用 を示した．このように THC による鎮痛作用の有効 用量は 2 つモデル間で分離しなかつたことから,

THC の有効量には注意が必要である.

6-2. 大麻による脳保護作用 大麻常習者の脳 に萎縮がみられることが報告されているがその後の 研究では一定の見解を得ていない. しかしながら, 新生児マウスに THC を投与すると視床の形態学的 変化が報告されている. ${ }^{25)}$ 一方， THC や CBD が多 発性硬化症や脳挫傷，脳虚血に有効であることが報
告され, 脳保護効果に脳内カンナビノイドが係わつ ていることが明らかになりつつある。 そこで，マウ スの中大脳動脈（middle cerebral artery; MCA）を 4 時間閉塞したモデルを用いて CBD の脳保護作用 について THC と比較検討した（Fig. 3).

6-2-1. 急性期-亜急性期：4 時間 MCA 閉塞 1 日 後の梗塞巣に対する CBD の抑制効果 CBD 3 $\mathrm{mg} / \mathrm{kg}$ の腹腔内投与は，4 時間 MCA 閉塞直前の投 与及び 4 時間 MCA 閉塞-再灌流 2 時間後の単回投 与でも梗塞巣を有意に抑制した。一方, THC 10 $\mathrm{mg} / \mathrm{kg}$ の腹腔内投与は，虚血直前の投与のみで梗 塞巣を抑制したことから，CBD は幅広い治療域を 有していることがわかった。 しかし，カンナビノー ルや $\beta-\mathrm{CPH}$ は改善しなかった。次に，その作用機 序を調べた結果，THC は虚血初期に起こるグル夕 ミン酸の過剰な遊離を， $\mathrm{CB}_{1}$ 受容体を介して抑制す ることにより脳保護効果を示すのに対して，CBD は， $\mathrm{CB}_{1}$ 受容体を介さず，虚血亜急性期に誘導され る白血球のマーカーである myeloperoxidase (MPO) の脳内浸潤抑制や脳血流の微小循環障害を改善する といつた抗炎症作用を持つことで脳保護効果を示し た.

6-2-2. 慢性期 : 4 時間 MCA 閉塞 1, 3, 5 日後か ら 14 日後までCBD を連続投与したときの治療効 果 $\quad \mathrm{CBD} 3 \mathrm{mg} / \mathrm{kg}$ を脳虚血 1 日後， 3 日後，5 日 後から 14 日後まで連続投与を行ったところ，脳虚 血 1 日後及び 3 日後からの投与では neurological 


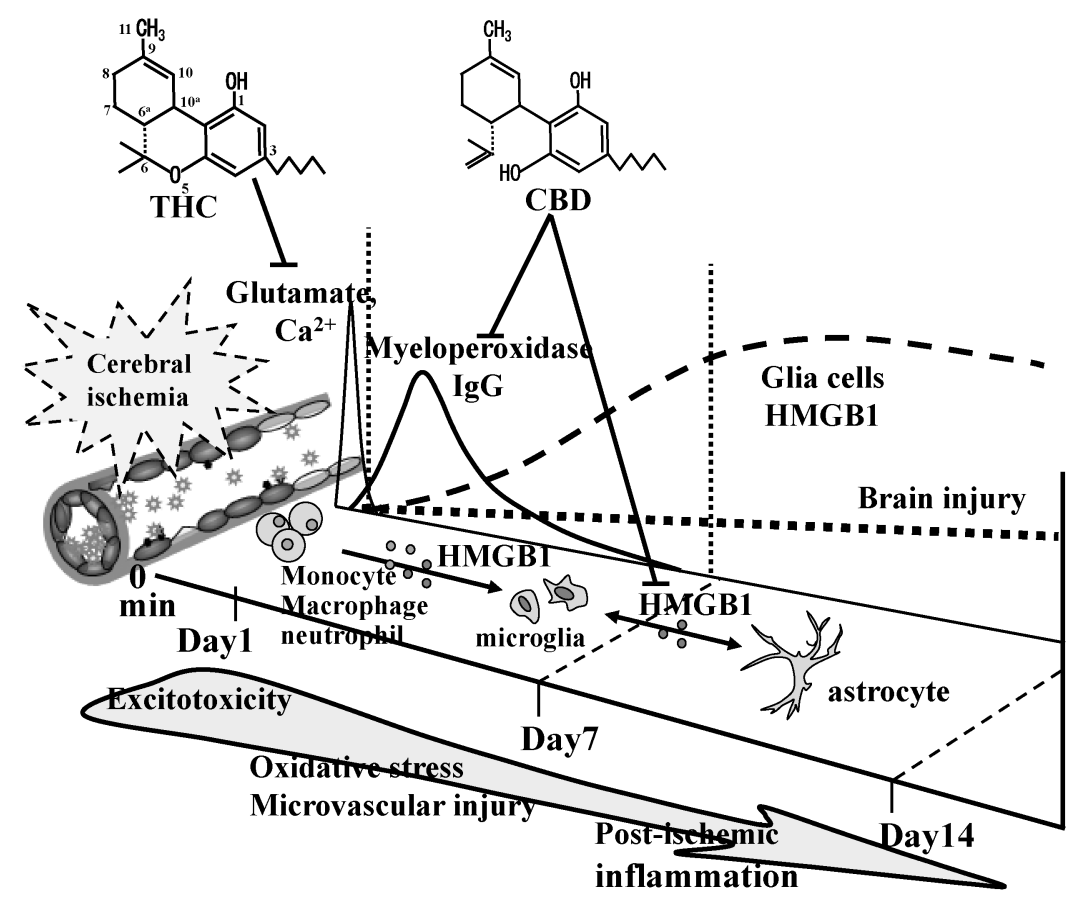

Fig. 3. Therapeutic Time Window of CBD and THC on Cerebral Ischemia in Mice

CBD $(3 \mathrm{mg} / \mathrm{kg})$ had a potent and long-lasting neuroprotective effect when administered both pre- and post-ischemia, whereas only pre-ischemic treatment with THC $(10 \mathrm{mg} / \mathrm{kg})$ reduced the infarction size when administered $24 \mathrm{~h}$ after $4-\mathrm{h}$ MCAO in mice. The neuroprotective effect of THC was related to the $\mathrm{CB}_{1}$ receptormediated inhibition of $\mathrm{Ca}^{2+}$ influx, glutamate release, and excitotoxicity. On the other hand, CBD had a potent and long-lasting neuroprotective effect, significantly inhibiting the myeloperoxidase activity of neutrophils at $1 \mathrm{~h}$ and $20 \mathrm{~h}$ after reperfusion, and suppressing the decrease in cerebral blood flow after reperfusion. In addition, CBD decreased the number of Iba1- and GFAP-positive cells. Moreover, $14 \mathrm{~d}$ of repeated treatment with CBD from day 1 after reperfusion improved survival and long-term functional deficits after cerebral ischemia, which suggests that CBD may be cerebroprotective during not only the early phase, but also the chronic phase after ischemic stroke.

score, 生存率について改善作用が認められたが, 5 日後からの投与ではいずれにおいても改善作用は 認められなかった.この結果から CBD の therapeutic time window は, 脳虚血が起こって 3 日後までが限 界であることが明らかとなつた，運動量と協調運動 に対しては，14 日間の連続投与により有意な改善 効果を示した。 CBD の 14 日間連続投与により TUNEL 陽性細胞の数は明らかに減少していた. CBD の 14 日間連続投与群では, 細胞体の小さなミ クログリアと放射状のアストロサイトが多数認めら れ，傷害性グリア細胞の増加を抑制していた。 CBD の 14 日間連続投与群では, 炎症性サイトカイ ンである high-mobility group box 1 (HMGB1) の血 中及び脳内の発現量を有意に低下させた。また，ミ クログリア選択的阻害剤である minocycline も同様 に血中 HMGB1 の発現量を弱いながらも低下さ せ，脳内 HMGB1 発現量を有意に減少させたこと から，脳内のミクログリアが HMGB1 を介して進 行的な炎症反応を広げていることが示唆された. ${ }^{26)}$

CBD は，精神作用が弱く，連続投与による耐性

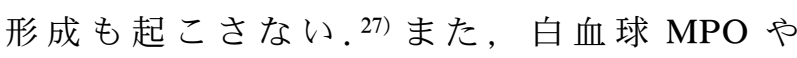
HMGB1 抑制による強い抗炎症作用により，虚血一 再灌流 2 時間後投与，あるいは 3 日後の投与でも脳 虚血性障害を抑制し，幅広い治療域（therapeutic time window）を示した（Fig. 3)。CBD が，脳虚 血後遅い夕イミングの投与でも脳保護効果を示すこ とやHMGB1 を抑制し脳虚血の進行を抑制するこ とを考えると，これまで脳梗塞 4.5 時間以内の急性 期治療の中心として用いられている t-PA と併用す ることにより治療効果の上昇が期待される. また, 脳梗塞再発の防止のために, アスピリンやチクロピ ジンなどの抗血栓療法が行われているが，CBDを 脳梗塞予後の治療薬のリード化合物として創薬され れば，治療効果の更なる上昇が期待され，脳梗塞後 の後遺症軽減にもつながり QOL を向上できるので はないかと考えられる.

\section{7. 動物実験から見た大麻の危険性}

7-1. THC によるウサギの脳波からみた脳機能 の異常 ウサギの脳波を測定すると, 皮質や扁桃 体では低電圧速波, 海馬では高電圧で 4-7 Hz（ $\theta$ 
波）の規則正しい同期波の海馬覚醒波がみられ，脳 波は覚醒パターンを示す。しばらくすると皮質や扁 桃体では高電圧の徐波成分が増加し，同時に海馬で は規則正しい $\theta$ 波の同期波がくずれ不規則になり， 脳波は傾眠パターンを示すようになる。 その状態に, THC $1 \mathrm{mg} / \mathrm{kg}$ を静脈注射すると，皮質では睡眠波 と覚醒波が交互に頻発するようになる。扁桃体や海 馬脳波も皮質脳波に同期した覚醒・睡眠パターンを 示すが，その電圧（振幅）が著明に低下することが 特徵で, 他の薬物にはみられない現象である.これ は，皮質と深部の脳部位の機能が乘離した状態を意 味しており，陶酔状態や幻覚を引き起こす原因の可 能性を示している.

\section{7-2. THC による異常行動の発現ラットに} $\mathrm{THC}$ を投与するとまず少量で現れる作用は運動量 の増加とカタレプシー様不動状態（抗精神病薬によ る錐体外路系障害と症状は類似しているが，作用機 序は異なる。詳細は後述）である。ささらに増量する と自発運動は逆に減少し，それとともに後ずさりや 下肢を軸として回転するような奇妙な行動が発現す る.これは幻覚薬にも共通してみられる異常行動で もある．また， THC の高用量は体温を低下させた り，Rota-Rod 法による協調運動も障害する，睡眠 薬による睡眠作用あるいは覚せい剂による運動量増 加作用のように相反する効果を THC はいずれも増 強する。しかし，CBDではこのような行動変化は みられない。

7-3. カタレプシー様不動状態の発現 ラット に無理に背伸びさせた格好で前肢を棒にかけたり, 後肢をコルク柱にかけ，逆立ちさせた不自然な姿勢 にすると，通常，すぐに正常姿勢に戻るが，抗精神 病薬のハロペリドールを投与すると錐体外路系症状 による運動機能障害であるカタレプシーが発現す る。一方, THCは, ハロペリドールによるカタレ プシーと類似のいつまでも不自然な姿勢をとり続け る。しかし，この不動状態は，単なる運動障害では なく音，光あるいは接触などの刺激によって容易に 元の正常姿勢に戻るが，ハロペリドールによるカタ レプシーは影響されなかった。このことは，THC による不動状態は，抗精神病薬の錐体外路症状によ る運動機能障害によるものとは異なることが示唆さ れる. したがって，われわれは，ハロペリドールに よるカタレプシーと区別するために THC による不
動状態を,「カタレプシー様不動状態」と名付けた. 次に, THCによるカタレプシー様不動状態の発現 機序を解明するために, 脳局所破壊及び脳内微量注 入実験を用いて発現に関与する脳部位の検討を行つ た。 その結果，脳局所破壊実験では，側坐核，扁桃 体，外側視床下部及び視床下部腹側内側核の破壊で 有意な発現抑制が認められ，中でも側坐核及び扁桃 体中心核破壊による影響が著明であり，淡蒼球，線 条体及び黒質破壞ではなんら影響を示さなかった。 一方，ハロペリドールによるカタレプシーに対して は，淡層球，線条体，黒質及び扁桃体中心核破壊で 有意な発現抑制が認められた。次に, THC の脳内 微量注入実験において, 側坐核, 扁桃体中心核や外 側視床下部及び視床下部腹内側核で有意なカタレプ

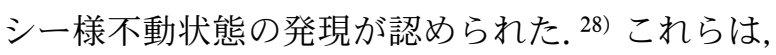
THC による不動状態の発現が運動機能に関与する 脳部位である錐体外路系の機能障害によるのではな く, 意欲や情動の座である大脳辺縁系（視床下部, 側坐核）の機能障害によるものである.すなわち, THC によるラットの不動状態はヒトの被暗示性の 増大あるいはうつ状態や無動機症候群をおこす可能 性を裏付けるものである.

大麻成分である $\mathrm{CBD} や ~ \beta-\mathrm{CPH}$, 内因性カンナ ビノイドの anandamideや 2-AGの全身投与, 脳室 内投与，側坐核内投与では，カタレプシー様不動状 態は生じなかった。一方, CB 受容体作動薬の HU-210 やWin55512 はカタレプシー様不動状態を 発現した.さらに THCによるカタレプシー不動状 態は, $\mathrm{CB}_{1}$ 受容体拮抗薬の SR141716A で抑制され たが， $\mathrm{CB}_{2}$ 受容体拮抗薬の AM630 では抑制されな かったことから，THCによるカタレプシー様不動 状態の発現は $\mathrm{CB}_{1}$ 受容体が重要であることがわ かった，次に，THCによるカタレプシー様不動状 態に対する神経伝達物質関連薬物の影響を調べた結 果, セロトニン受容体作動薬の 5-MeODMT, セロ トニン選択的取り込み阻害薬のパロキセチン, NMDA 受容体拮抗薬のアマンタジンや MK-801 が 最も効果的であった。 さらに，THCによるカタレ プシー様不動状態の発現時の側坐核からのドパミ ン，ノルアドレナリン，セロトニン，グルタミン酸 の遊離についてマイクロダイアリシス法を用いて検 討した。 その結果，それぞれの神経伝達物質の経時 的な変化から, THCによるカタレプシー様不動状 


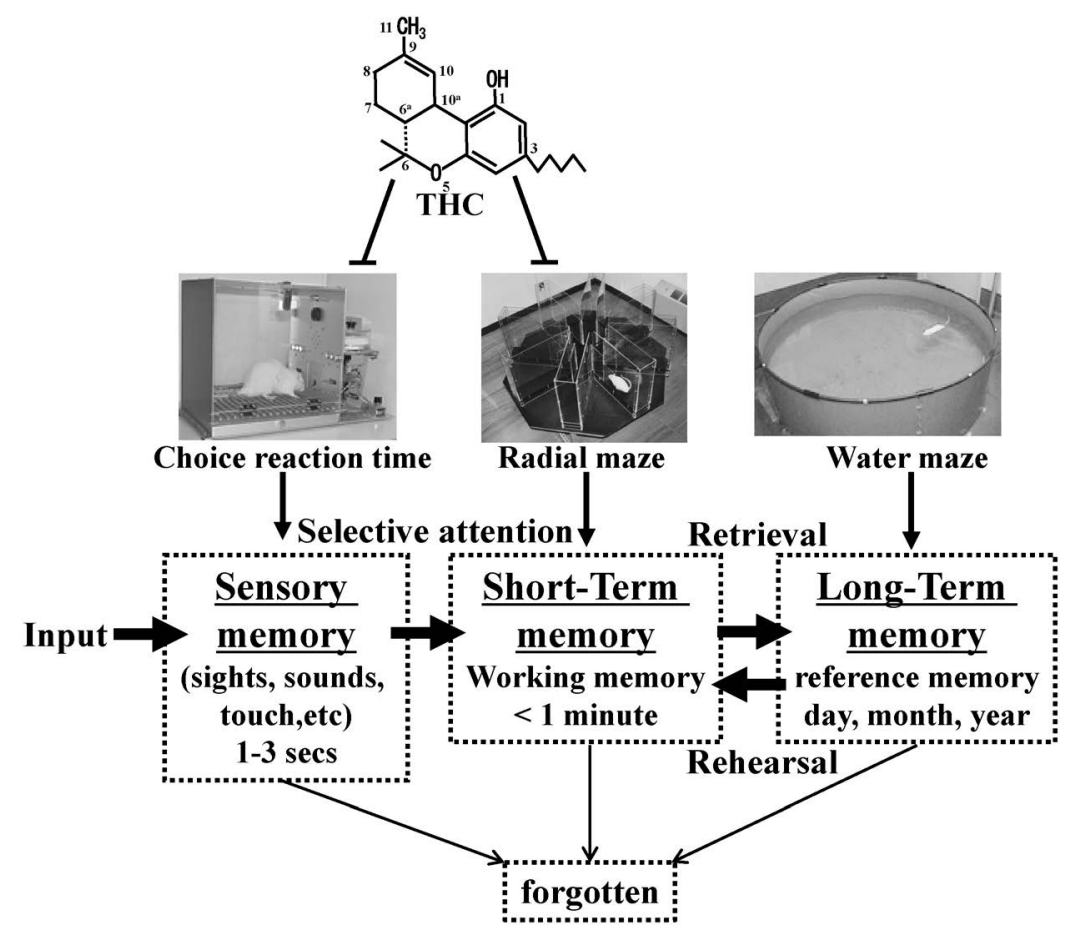

Fig. 4. Selective Impairment of THC in the Multi-store Model of Memory in Rats

THC $(10 \mathrm{mg} / \mathrm{kg}$, i.p.) produced a marked increase in both choice reaction time (CRT) and the number of total lever pressings in a two-lever CRT task. THC $(6 \mathrm{mg} / \mathrm{kg}$, i.p.) impaired spatial memory in an eight-arm radial maze based on working memory, but not in a water maze based on reference memory. These results suggest that THC-induced impairments in learning and memory are based on the selective impairment of selective attention and working memory through effects on attentional processes.

態は，グルタミン酸遊離低下を基盤にしてドパミン 遊離上昇，セロトニン遊離低下そしてノルアドレナ リン遊離上昇と連鎖的に動いており，しかも，これ ら神経系の機能変化は， $\mathrm{CB}_{1}$ 受容体を介した作用で あることを明らかにした。 さらに，MK-801 が側坐 核からのセロトニン遊離低下を改善したことから, 側坐核の $\mathrm{CB}_{1}$ 受容体を介したセロトニン神経とグ ルタミン酸神経の機能低下が，THC によるカタレ プシー様不動状態の発現に重要であることを示唆し た。 大麻を長期乱用すると，ヒトにおいて感情の平 板化，自発性の減退及び思考力の低下などの無動機 症候群（amotivational syndrome）といつた精神障

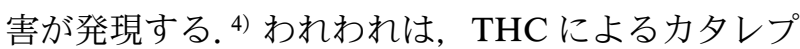
シー様不動状態が，意欲低下モデルとして有用であ ることを提唱している.

7-4. THCによる学習・記憶障害 ヒトがあ る情報を学習, 記憶する場合に二重貯蔵モデルが考 えられている (Fig. 4). ${ }^{29)}$ ある情報が五感を利用し て感覚貯蔵に入力された後，注意を向けられた情報 が作業記憶や参照記憶に移行される。これら 3 つの 学習・記憶過程に対する THC の作用を調べるため
に，オペラント装置を用いた選択反応時間課題，8 方向放射状迷路課題，水迷路課題を利用した（Fig. 4). ${ }^{30)}$

選択反応時間課題：この課題は，感覚記憶から得 た情報が，短期及び長期記憶に移る最初の過程の選 択的注意機構を測定できる方法で，臨床及び動物実 験でも利用されている。動物の選択反応時間課題 は，左右 2 つの応用レバーの上に，それぞれ キューランプが設けられたオペラント装置であり， キューランプ点灯後のレバーを押すまでの時間を選 択反応時間とし，試行間隔中のレバー押し行動数を 評価に用いる。 その課題において，THC は選択反 応時間が延長し，それに伴って尚早反応や固執行動 などの異常なレバー押し行動がみられた。この選択 的注意機構は, attention, arousal, decision-making, motivation などが密接に係わり，いかに記憶を強く 留めておけるかを左右し，当然，意欲や動機によつ ても変化することから，大麻の吸煙による感覚異常 や意欲の低下に THC が強く関与していることを示 している.

8 方向放射状迷路課題：この装置は 8 方向に伸び 
たアームの先端に慨が置いてあり，これらの餌をす べて取ることを訓練されたラットは，一度䬺を取り 終えたアームには二度と入ることなく 8 個の餌をう まく取るようになる。この遂行のためにラットは床 の臭いを手がかりとしているのではなく周りの環境 との位置関係で行っている.この課題は, 従来の迷 路学習が決められた出発とゴールの反復選択（winstay）であるのに対し，出発とゴールは一定でなく ラットが最初に選んだ選択肢が出発箱である。ま た，正選択も決まっておらず，次の選択で正選択 （餌のある未選択肢）と誤選択（餌を既に取つた選 択肢に再び訪れる）が定まり，しかも二者択一でな く複数である移行選択（win-shift）を利用している のが特徴である。このことから，作業記憶を測定で きると考えられている。この課題で修得したラット の空間記憶を THC は低用量で障害し，餌のない アームに何度も入るようになる。すなわち，空間記 憶を基盤とした作業記憶が THC によって著明に障 害をうけたことを示している. 次に, THCによる空 間記憶障害の発現部位を探るために，脳内の 15 力 所に THC を微量注入した結果，背側海馬（dorsal hippocampus; DH)，腹側海馬（ventral hippocampus；VH）や視床背内側核への微量注入によって著

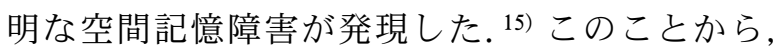
DH 及び VH からのアセチルコリン及び 5-HT 遊離 量に対する THC の影響を調べるためにマイクロダ イアリシス法を用いて測定した。その結果，THC は DH 及び VH からのアセチルコリン遊離量を著 明に低下させた。さらに，空間記憶障害の発現に重 要であった 5-HT の遊離量の測定については, 蛍光 誘導体化法（ベンジルアミンと 5-ヒドロキシイン ドール類の反応で生じる強蛍光性オキサゾール化合 物を測定)を利用した結果, 他の伝達物質に比べて,

VH からの 5-HT 遊離量は THC によって著明に抑 制された。次に，諸種の神経伝達物質に関連する薬 物を用いて調べた結果，カンナビノイド受容体や $5-\mathrm{HT}_{2}$ 受容体が，THCによる空間記憶障害の発現 に係わっていると考えられた。

水迷路課題：この課題は, 場所認知を調べること ができる点では，8 方向放射状迷路課題と同じだ が，出発とゴールの反復選択であるため，参照記憶 を測定できる，装置は，水を張つた直径 $150 \mathrm{~cm}$ の 円形プールで，ゴールのプラットホームは泳いでい
るラットからはみえないように水面下 $2 \mathrm{~cm}$ の高さ にプールの壁に近いところに置いてある.このよう な特徵を持った水迷路課題において，THC は影響 しなかった。このことから, THC は場所，空間の 配置の認知，参照記憶に対してはなんら影響を及ぼ さないことがわかった.

以上の 3 つの学習・記憶課題から, THC は, 選 択的注意機構や作業記憶が障害されること，さら に，水迷路課題の結果から，大麻の幻覚作用による 空間・場所や形の歪曲を起こした結果ではなく，海 馬などの脳高次機能に作用した結果，学習・記憶障 害を引き起こしたと考えられる。

\section{8. ラットの超音波発声を利用した刺激条件に応 じた THCの 2 相性}

ヒトが大麻を摂取すると，平衡感覚，空間感覚， 視覚や聴覚など感覚機能に異常を生じる。そのた め, 音, 接触, 光などの外来刺激に対して過度の反 応を示すことがある。しかし，動物実験レベルで は，このようなヒトでの大麻草による感覚異常の報 告は少ない，これまでのわれわれの研究では，上述 したように，THCによるカタレプシー様不動状態 において音や空気刺激を負荷すると，一瞬で不動状 態が解けることや，von Frey test 及び prepulse inhibition testにおいて，THC は接触刺激，音刺激に

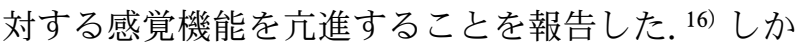
し，これらの実験は，拘束下で定量性がない主観的 な評価系であった。そこで，われわれは，ラットが 発声する超音波に着目して，大麻による感覚機能を 測定できる評価系が確立できないかと考えた。

超音波は，ヒトが感知できない高い周波数帯 （20 kHz 以上）の音である．䛚歯類は，超音波発声 （ultrasonic vocalizations）を介してコミュニケー ションをとることが知られている. ${ }^{31)}$ 近年の超音波 発声に関する研究から，ラットが発声する超音波は 大きく 3 分類され，成熟期の高周波数帯（45$100 \mathrm{kHz})$ 及び低周波数帯 $(20-30 \mathrm{kHz})$ と, 新生 児期の高周波数帯がある。成熟ラットでは，薬物や 環境など生体外刺激によって，感覚運動野を介して 喉頭（声門）から超音波を発声する特徵があ

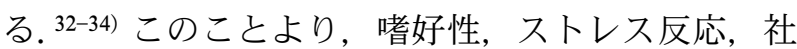
会性・協調性などの生理行動又は情動行動の指標と して超音波発声が用いられている。このような超音 波発声の特性を利用して，われわれは感覚機能に対 


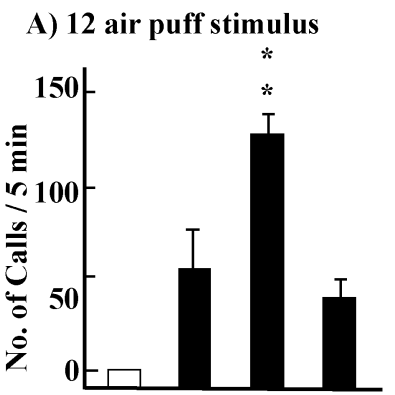
vehicle $1 \quad 3 \quad 10$ THC (mg/kg, i.p.)
(10) (10) (9) (9)

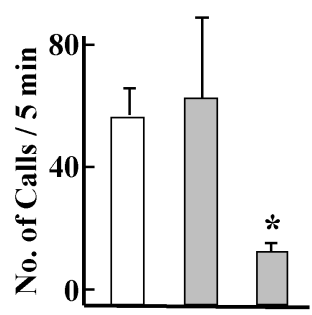

(9) (9) (9)

vehicle $3 \quad 10$

THC (mg/kg , i.p.)
B) 36 air puff stimulus

Fig. 5. Biphasic Effect of THC on 22-kHz Ultrasonic Vocalizations after an Aversive Air-puff Stimulus in Rats

Ultrasonic vocalizations were measured $60 \mathrm{~min}$ after i.p. administration of THC at 1,3 , and $10 \mathrm{mg} / \mathrm{kg}$ or vehicle. The numbers of $22-$ and $50-\mathrm{kHz}$ ultrasonic vocalizations were measured after (A) 12 and (B) 36 air puff stimuli in adult rats. Values are expressed as mean \pm S.E.M. ${ }^{*} p<0.05$, ${ }^{* *} p<0.01 v s$. vehicle group (Dunnett's test).

する大麻の作用を検討した. ${ }^{35}$

感覚機能を評価するために, 触覚刺激として空気 刺激（0.3 MPa，1 秒間隔で負荷）を利用した結果， 12 回の空気刺激では低周波数帯の超音波発声は認 められず，36 回の空気刺激では低周波数帯の超音 波発声数が有意に増加した。つまり，空気刺激の回 数に依存して低周波数帯の超音波発声が増加した.

この 2 種類の空気刺激の回数を用いて大麻成分の影 響を検討した。その結果，36 回の空気刺激負荷に 対して, THC $10 \mathrm{mg} / \mathrm{kg}$ は低周波数帯の発声回数を 抑制した。一方，12 回の空気刺激負荷に対して, $\mathrm{CBD}$ 及び $\beta$-CPH は超音波の発声数に影響しな かったが, THC $3 \mathrm{mg} / \mathrm{kg}$ は低周波数帯の発声回数 を増加させた。これらの結果から，大麻による触覚 機能への影響は，THC のみが関与し，刺激の強さ と THC の用量によって触覚過敏作用と鈍麻作用が 発現する複雑な作用であることがわかった (Fig. 5).

次にその作用機序を調べた結果， $\mathrm{CB}_{1}$ 受容体拮抗 薬 SR141716 及び $\mathrm{CB}_{1}$ 受容体ネガティブアロステ リックモデュレーターCBD は，空気刺激 12 回負 荷後の THC による低周波数帯の超音波発声回数の 増加作用を有意に抑制した。しかし， $\mathrm{CB}_{2}$ 受容体拮 抗薬 AM630 は発声回数を抑制しなかった。これら のことから，THCによる触覚過敏作用は $\mathrm{CB}_{1}$ 受容 体を介して発現すること，また，CBD が THCの 作用を抑制したことから，大麻中の成分同士が複雑 に作用しあっていることが示唆された。
本研究は，ラット超音波発声を用いて，非拘束下 で簡便で客観的かつ定量性のある新規触覚機能の評 価系として有用であることを示した。この評価系 は, 触覚機能の発現機序の解明やその新薬開発への 応用が期待できる。.また，大麻成分 THC の薬理作 用には，触覚機能に対する過敏作用と鈍麻作用があ ることを動物実験レベルで初めて明らかにし， $\mathrm{CB}_{1}$ 受容体が感覚刺激の強さによって感じ方が変わる仕 組みに関与していることを解明した。

\section{9. おわりに}

本稿で示したように THC は有用性と危険性の両 方を持ち合わせている。一方，CBD は中枢作用が 弱く, 抗炎症作用が比較的強いと考えられるが, THC の薬理作用に対して相乗作用と拮抗作用を有 する. ${ }^{10,36)}$ また, 内因性カンナビノイド類の anandamide や 2-AG の薬理作用は THC と異なるとこ ろがある。このように大麻成分の薬理作用は多彩で あり，モルヒネに比べると臨床応用可能な面がたく さんあることは非常に興味深い。そのためには，そ れぞれの薬理作用を明確にし，臨床応用できる面と そうでない面の区別をしっかり整理する必要があ る. 今後, さらに, 生体内のカンナビノイドシステ ムの役割や新たな受容体サブタイプの発見などがな されれば，多彩な大麻成分の薬理作用が，それぞれ に応じた疾患に対する新しい薬物開発につながるも のと期待される.

謝辞 本研究に使用した THC については，九 州大学薬学部生薬学教室の正山征洋教授並びに薬用 資源制御学分野の森元 聡教授より提供を受けたも ので，感謝の意を表します．また，本研究は JSPS 科研費（15K08606）並びに国立精神・神経医療研 究センター精神・神経疾患研究開発費の助成を受け て実施されたものである.

\section{利益相反＼cjkstart開示すべき利益相反はない.}

\section{REFERENCES}

1) The Public Relations Office of the Government of Japan: 〈https://www.gov-online.go.jp/ useful/article/201806/3.html\#section5 $\rangle$, cited 23 May, 2019.

2) Executive Office of the President of the United 
States of America, "National Drug Control Strategy 2016," Office of National Drug Control Strategy Policy, Washington, D.C., 2016.

3) Akutsu M., Yakugaku Zasshi, 139, 693-697 (2019) .

4) Brunton L. L., Hial-Dandan R., Knollmann B. C., "Goodman and Gilman's The Pharmacological Basis of Therapeutics," 13th ed., Pergamon Press, New York, 2018, pp. 440441.

5) Ohlsson A., Lindgren, J. E., Wahlen A., Agurell S., Hollister L. E., Gillespie H. K., Clin. Pharmacol. Ther., 28, 409-416 (1980).

6) Isbell R., Gorodetzsky C. W., Jasinski D., Claussen U., Spulak F. V., Korte F., Psychopharmacology (Berl.), 11, 184-188 (1967) .

7) Izzo A. A., Borrelli F., Capasso R., Di Marzo V., Mechoulam R., Trends Pharmacol. Sci., 30, 515-527 (2009).

8) Christensen H. D., Freudenthal R. I., Gidley J. T., Rosenfeld R., Boegli G., Testino L., Brine D. R., Pitt C. G., Wall M. E., Science, 172, 165-167 (1971).

9) Dewey W. L., Pharmacol. Rev., 38, 151-178 (1986) .

10) Boggs D. L., Nguyen J. D., Morgenson D., Taffe M. A., Ranganathan M., Neuropsychopharmacology, 43, 142-154 (2018) .

11) Schramm-Sapyta N. L., Cha Y. M., Chaudhry S., Wilson W. A., Swartzwelder H. S., Kuhn C. M., Psychopharmacology (Berl.), 191, 867-877 (2007) .

12) Cutler M. G., Mackintosh J. H., Psychopharmacologia, 44, 287-289 (1975).

13) Ueki S., Fujiwara M., Ogawa N., Physiol. Behav., 9, 585-587 (1972).

14) Nagai H., Egashira N., Sano K., Ogata A., Mizuki A., Mishima K., Iwasaki K., Shoyama Y., Nishimura R., Fujiwara M., Pharmacol. Biochem. Behav., 84, 330-336 (2006).

15) Egashira N., Mishima K., Iwasaki K., Fujiwara M., Brain Res., 952, 239-245 (2002).

16) Sano K., Koushi E., Irie K., Higuchi S., Tsuchihashi R., Kinjo J., Egashira N., Oishi R., Uchida N., Nagai H., Nishimura R., Tanaka H., Morimoto S., Mishima K., Iwasaki K., Fujiwara M., Biol. Pharm. Bull., 32, 2065-2067 (2009).
17) Schlicker E., Kathmann M., Trends Pharmacol. Sci., 22, 565-572 (2001).

18) Fay J. F., Farrens D. L., Biochemistry, 52, 8286-8294 (2013).

19) Devane W. A., Hanus L., Breuer A., Pertwee R. G., Stevenson L. A., Griffin G., Gibson D., Mandelbaum A., Etinger A., Mechoulam R., Science, 258, 1946-1949 (1992).

20) Sugiura T., Kondo S., Sukagawa A., Nakane S., Shinoda A., Itoh K., Yamashita A., Waku K., Biochem. Biophys. Res. Commun., 215, 89-97 (1995).

21) Mechoulam R., Ben-Shabat S., Hanus L., Ligumsky M., Kaminski N. E., Schatz A. R., Gopher A., Almog S., Martin B. R., Compton D. R., Pertwee R. G., Griffin G., Bayewitch M., Barg J., Vogel Z., Biochem. Pharmacol., 50, 83-90 (1995).

22) Kano M., Ohno-Shosaku T., Hashimotodani Y., Uchigashima M., Watanabe M., Physiol. Rev., 89, 309-380 (2009).

23) Rioli V., Gozzo F. C., Heimann A. S., Linardi A., Krieger J. E., Shida C. S., Almeida P. C., Hyslop S., Eberlin M. N., Ferro E. S., J. Biol. Chem., 278, 8547-8555 (2003).

24) Heimann A. S., Gomes I., Dale C. S., Pagano R. L., Gupta A., de Souza L. L., Luchessi A. D., Castro L. M., Giorgi R., Rioli V., Ferro E. S., Devi L. A., Proc. Natl. Acad. Sci. USA, 104, 20588-20593 (2007).

25) Itami C., Huang J. Y., Yamasaki M., Watanabe M., Lu H. C., Kimura F., J. Neurosci., 36, 7039-7054 (2016).

26) Hayakawa K., Mishima K., Fujiwara M., Pharmaceuticals (Basel), 3, 2197-2212 (2010).

27) Hayakawa K., Mishima K., Nozako M., Ogata A., Hazekawa M., Liu A. X., Fujioka M., Abe K., Hasebe N., Egashira N., Iwasaki K., Fujiwara M., Neuropharmacology, 52, 10791087 (2007).

28) Sano K., Mishima K., Koushi E., Orito K., Egashira N., Irie K., Takasaki K., Katsurabayashi S., Iwasaki K., Uchida N., Egawa T., Kitamura Y., Nishimura R., Fujiwara M., Neuroscience, 151, 320-328 (2008).

29) Atkinson R. C., Shiffrin R. M., Sci. Am., 225, 82-90 (1971).

30) Mishima K., Egashira N., Hirosawa N., Fujii 
M., Matsumoto Y., Iwasaki K., Fujiwara M., Jpn. J. Pharmacol., 87, 297-308 (2001) .

31) Portfors C. V., J. Am. Assoc. Lab. Anim. Sci., 46, 28-34 (2007).

32) Ishiyama S., Brecht M., Science, 354, 757-760 (2016).

33) Mahrt E., Agarwal A., Perkel D., Portfors C., Elemans C. P., Curr. Biol., 26, R880-R881 (2016).

34) Brudzynski S. M., Behav. Brain Res., 182, 261-273 (2007).
35) Myose T., Shirakawa A., Irie K., Yamashita Y., Nakano T., Takase Y., Matsuo K., Satho T., Tuchihashi R., Kinjo J., Tanaka H., Morimoto S., Funada M., Sano K., Mishima K., Neurosci. Lett., 701, 132-135 (2019) .

36) Hayakawa K., Mishima K., Hazekawa M., Sano K., Irie K., Orito K., Egawa T., Kitamura Y., Uchida N., Nishimura R., Egashira N., Iwasaki K., Fujiwara M., Brain Res., 1188, 157-164 (2008). 